\title{
OPEM
}

www.opem.org

Oriental Pharmacy and Experimental Medicine 2008 8(2), 164-170

DOI 10.3742/OPEM.2008.8.2.164

\section{Antioxidant and hepatoprotective action of the crude ethanolic extract of the flowering top of Rosa damascena}

\author{
MA Alam ${ }^{1, *}$, MAB Nyeem ${ }^{2}$, MA Awal ${ }^{2}$, M Mostofa ${ }^{2}$, MS Alam ${ }^{3}$, N Subhan ${ }^{4}$ and M Mostafizur \\ $\operatorname{Rahman}^{1}$ \\ ${ }^{1}$ Department of Pharmacy, Stamford University, Bangladesh; ${ }^{2}$ Department of Pharmacology, Bangladesh \\ Agricultural University, Bangladesh; ${ }^{3}$ Department of Agriculturalchemistry, Bangladesh Agricultural University, \\ Bangladesh; ${ }^{4}$ Department of Pharmacy, Khulna University, Pharmacology Laboratory, Department of \\ Pharmacology, Bangladesh Agricultural University, Mymensingh-2202, Bangladesh
}

Received for publication May 14, 2007; accepted October 10, 2007

\begin{abstract}
SUMMARY
The hepatoprotective activity of the alcoholic extract of Rosa damascena was studied against paracetamol induced acute hepatotoxicity in rats. Liver damage was assessed by estimating serum enzyme activities of aspartate aminotransferase, alanine aminotransferase, alkaline phosphatase and histopathology of liver tissue. Pre- and post-treatment with ethanolic extracts showed a dose-dependent reduction of paracetamol induced elevated serum levels of enzyme activity. The mechanism underlying the protective effects was assayed in vitro and the $R$. damascena extracts displayed dosedependent free radical activity using DPPH $\left(\mathrm{IC}_{50}=162.525 \mu \mathrm{g} / \mathrm{ml}\right)$ and TBA method. The hepatoprotective action was confirmed by histopathological observation. The ethanolic extracts reversed paracetamol induced liver injury. These results suggest that the hepatoprotective effects of $R$. damascena extracts are related to its antioxidative activity.
\end{abstract}

Key words: Antioxidant; Paracetamol; Rosa damascene; Liver enzyme

\section{INTRODUCTION}

Rosa damascena Mill. (Rosaceae) is a well known flowering plants and cultivated in rose gardens in several places in Bangle, Kashmir and Punjab. Enormous quantity of wild hill roses grows throughout the North West Himalayas and Kashmir (Joshi, 1994). Essential oil, quarcetin, kampferol and cyanidine have been isolated from whole plant (Joshi, 1994). Cyanidin 3, 5-di-glucoside has been isolated from petals and flowers also

\footnotetext{
*Correspondence: MA Alam, Department of Pharmacy, Stamford University, 51, siddeswari road, Dhaka-1209, Bangladesh. E-mail: sonaliagun@yahoo.com
}

contain a bitter principle, tannin content, fatty oil and organic acids (Joshi, 1994). The tetrahydroxyflavanone (kaempferol, 1) isolated from the methanol extract was effective in reducing the maturation of infectious progeny virus apparently due to selective inhibition of the viral protease (Mahmood et. al., 1996). On the other hand the pentahydroxyflavone (quercetin, 2) and two 3substituted derivatives of kaempferol appeared to inhibit HIV-infection by preventing binding of gp120 to CD4 and 2-Phenylethanol-O-(6-O-galloyl)beta-D-glucopyranoside interacted irreversibly with gp120 and neutralized virus infectivity (Mahmood et. al., 1996). The essential oil of $R$. damascena petals 
was evaluated for its antibacterial effects against three strains of Xanthomonas axonopodis spp. vesicatoria. (Basim and Basim, 2003) The rose teas were rich in free gallic acid. The highest values of antioxidant activity, total phenols, and gallic acid contents were found. (Vinokur et al., 2006) Achuthan et al. reported that $R$. damascena could protect against $\mathrm{CCl}_{4}$ induced hepatotoxicity, possibly by its free radical scavenging activity. (Achuthan et al., 2003) R. damascena also has a high ability to inhibit lipid peroxidation in rat model. (Shahriari et al., 2006).

As a part of the on-going investigations on Bangladeshi plants for phytochemical, and pharmacological properties (Alam et al., 2006a,b) we now report on the hepatoprotective potential of the ethanolic extracts of the flowering tops of $R$. damascena in rat.

\section{MATERIALS AND METHODS}

\section{Plant material}

The flowering tops of $R$. damascena were collected from the Gazipur, Dhaka, Bangladesh in December 2005 and identified by the experts of Bangladesh National Herbarium, Dhaka and the sample has been preserved in Pharmacology Laboratory, Bangladesh Agricultural University.

\section{Preparation of ethanol extracts}

Dried ground flowering tops ( $400 \mathrm{~g}$ ) were extracted with $95 \%$ of ethanol in a Soxhlet apparatus at an elevated temperature. The extract was concentrated by evaporation under reduced pressure at $40^{\circ} \mathrm{C}$ using Buchi rotary evaporator to have gummy concentrate of reddish black colour extract (yield appx. 5.6\%).

\section{Animals}

Swiss albino rat of either sex (120 - $140 \mathrm{~g})$ were obtained from the Animal house of the International Centre for Diarrhoeal Disease and Research, Bangladesh (ICDDR, B). The animals were housed under standard laboratory conditions (relative humidity $55-65 \%$, r.t. $23.0 \pm 2.0^{\circ} \mathrm{C}$ and $12 \mathrm{~h}$ light: dark cycle). The animals were fed with standard diet and water ad libitum. The University Animal Research Ethical Committee approved the experimental protocol.

\section{Antioxidant activity by DPPH scavenging assay of R. damascena}

Antioxidant activity of the ethanolic extract was determined on the basis of their scavenging activity of the stable DPPH free radical. Quantitative assay was performed on the basis of the modified method of Gupta et al. (2003). Stock solutions (10 $\mathrm{mg} / \mathrm{ml}$ ) of the plant extracts were prepared in ethanol from which serial dilutions were carried out to obtain concentrations of 1, 5, 10, 50, 100 and $500 \mathrm{mg} / \mathrm{ml}$. Diluted solutions $(2 \mathrm{ml})$ were added to $2 \mathrm{ml}$ of a $0.004 \%$ ethanol solution of DPPH, mixed and allowed to stand for $30 \mathrm{~min}$ for reaction to occur. The absorbance was determined at $517 \mathrm{~nm}$ and from these values corresponding percentage of inhibitions were calculated as

$\%$ inhibition= $=($ Blank OD - Sample OD/Blank OD $) \times 100$. $(\mathrm{OD}=$ Optical density)

Then $\%$ inhibitions were plotted against concentration and from the graph $\mathrm{IC}_{50}$ was calculated using probit equation. The experiment was performed in duplicate and average absorption was noted for each concentration. Ascorbic acid was used as positive control.

\section{Estimation of anti- $\mathrm{FeCl}_{2}-\mathrm{H}_{2} \mathrm{O}_{2}$-induced linoleic acid peroxidation}

The effect of anti- $\mathrm{FeCl}_{2}-\mathrm{H}_{2} \mathrm{O}_{2}$-induced linoleic acid peroxidation was determined according to the method of Tamura and Shibamoto. (Tamura and Shibamoto, 1991) A mixture $(5 \mathrm{ml})$ containing ethanolic extracts of $R$. damascena (0 - 900 ppm, relative to linoleic acid), linoleic acid $(0.1 \mathrm{M}), \mathrm{FeCl}_{2}$ (0.4 mM), $\mathrm{H}_{2} \mathrm{O}_{2}(0.4 \mathrm{mM})$, and phosphate buffer 
$(0.2 \mathrm{M}, \mathrm{pH} 7.4)$ was incubated at $37^{\circ} \mathrm{C}$ for $24 \mathrm{~h}$. After incubation, $1.0 \mathrm{ml}$ of thiobarbituric acid (TBA) $(1 \%)$, and $1.0 \mathrm{ml}$ of $\mathrm{HCl}(10 \%)$ were added to the mixture, which was heated for $30 \mathrm{~min}$ on a boiling water bath. After cooling, chloroform $(5.0 \mathrm{ml})$ was added and the mixture centrifuged at $1,000 \mathrm{~g}$ to give a supernatant. The absorbance of supernatant was measured spectrophotometrically at $532 \mathrm{~nm}$. A low absorbance value indicated a high antioxidant activity.

\section{Paracetamol induced hepatic necrosis protection} of the crude extract

The bioassays were conducted according to the World Health Organization guidelines for the evaluation of the safety and efficiency of herbal medicine (WHO, 1992). Four groups of 6 rats (Table 1) received the plant extract by intra gastric gavages at the dose of $1.5 \mathrm{~g} / \mathrm{kg}$ body weight and $3 \mathrm{~g} / \mathrm{kg}$ body weight. Tween 80 was used as a carrier of $R$. damascena extract ( 1.5 and $3 \mathrm{~g} / \mathrm{kg}$ body weight/day) as well as for paracetamol $(3 \mathrm{~g} / \mathrm{kg}$ body weight), administered per orally three times a week for 14 days. Higher doses have been selected considering the dosing frequency and experimental period. At the end of the experimental period (14 days) the rats were fasted overnight, blood samples for biochemical assay were collected from animals by tail-tip cutting and sacrificed under ether anaesthesia. The liver were collected and after instantaneous washing a part of the liver tissue was kept in $10 \%$ formalin solution for further histopathological studies.

\section{Biochemical assays}

Activity of aspertate aminotransferase (AST), alanine aminotransferase (ALT) and alkaline phosphatase (ALP) were determined using an auto analyser (Reflotron Plus ${ }^{\circledR}$, Germany).

\section{Histopathological study}

Liver immersed in 10\% buffer formalin solution, representative blocks of tissue from each lobe were taken. Following over night fixation in $10 \%$ formalin, the tissue blocks were gradually dehydrated in ascending concentration of ethyl alcohol. Then it was properly oriented in molten paraffin for making blocks and sectioning. A paraffin bath with a temperature of $60^{\circ} \mathrm{C}$ to $70^{\circ} \mathrm{C}$ was used. The melting point of paraffin was $58^{\circ} \mathrm{C}$. The tissues were treated in paraffin melted in for $1 \mathrm{~h}$. The tissue was carefully embedded in proper plane. The paraffin was then allowed to harden at room temperature. A properly sharpened microtome knife was used for section cutting. A water bath with a temperature of $45-50^{\circ} \mathrm{C}$ was used for floatation of the samples. Sections were cut at 6 micron thickness. Ribbons of sections were selected and placed on the water bath. Then sections were taken on glass slides previously smeared with egg

Table 1. Levels of serum AST, ALT, and ALP in control and experimental groups of rats

\begin{tabular}{llccc}
\hline Group & Treatment & $\begin{array}{c}\text { Mean serum } \\
\text { AST level } \\
(\mathrm{U} / \mathrm{L}) \pm \text { S.D. }\end{array}$ & $\begin{array}{c}\text { Mean serum ALT } \\
\text { level. } \\
(\mathrm{U} / \mathrm{L}) \pm \text { S.D. }\end{array}$ & $\begin{array}{c}\text { Mean serum ALP } \\
\text { level } \\
(\mathrm{U} / \mathrm{L}) \pm \text { S.D. }\end{array}$ \\
\hline Group-I & Control (Normal food and water only) & $27.87 \pm 1.98$ & $28.52 \pm 1.68$ & $18.21 \pm 1.04$ \\
\hline Group-II & $\begin{array}{l}\text { Treated with paracetamol } \\
(3 \mathrm{~g} / \mathrm{kg} \text { body weight) }\end{array}$ & $62.63 \pm 1.35^{\mathrm{a}}$ & $67.73 \pm 2.44^{\mathrm{a}}$ & $22.12 \pm 1.34^{\mathrm{b}}$ \\
\hline Group-III & $\begin{array}{l}\text { Paracetamol + ethanol extract } \\
(1.5 \mathrm{~g} / \mathrm{kg} \text { bd. Wt. })\end{array}$ & $55.91 \pm 3.43^{\mathrm{c}}$ & $63.40 \pm 3.38^{\mathrm{d}}$ & $22.00 \pm 1.41^{\mathrm{e}}$ \\
\hline Group-IV & $\begin{array}{l}\text { Paracetamol }+ \text { ethanol extract } \\
(3 \mathrm{~g} / \mathrm{kg} \text { bd. Wt. })\end{array}$ & $48.34 \pm 2.68^{\mathrm{a}}$ & $57.38 \pm 2.98^{\mathrm{a}}$ & $20.48 \pm 0.42^{\mathrm{d}}$ \\
\hline
\end{tabular}

Values are statistically significant at $P<0.05 .{ }^{\mathrm{a}} P<0.001,{ }^{\mathrm{b}} P<0.01,{ }^{\mathrm{c}} P<0.005,{ }^{\mathrm{d}} P<0.025,{ }^{\mathrm{e}} P<0.10$ vs control, Student's $t$-test; values are mean \pm S.E. $(\mathrm{N}=6)$. Comparison are made as Group I and Group II; Group II and Group III; Group II and Group IV. 
albumin. The slides were kept in slanting position for some time to drain-out the water and then allowed to dry at room temperature. Sections of liver were stained using Haematoxylin and Eosin (H \& E) stain.

\section{Statistical analysis}

Experimental values were expressed as mean \pm S.E.M. Independent sample $t$-test was done for statistical comparison. Statistical significance was considered to be indicated by a $P$ value $<0.05$ in all cases.

\section{RESULTS}

\section{Antioxidant assay}

Antioxidant activity of the ethanolic extract of $R$. damascena was performed on the basis of the modified method of Gupta et al. (2003). The extract showed excellent antioxidant activity $\left(\mathrm{IC}_{50}\right.$ about $162.525 \mu \mathrm{g} / \mathrm{ml}$ ) against DPPH free radical comparable to that of standard drug, ascorbic acid ( $\mathrm{IC}_{50}$ about $64.307 \mathrm{mg} / \mathrm{ml}$ ) (Fig. 1). The free radical scavenging property may be one of the mechanisms by which the plants are effective in traditional medicine.

Fig. 2 shows the antioxidant activity of $R$. damascena extract in the linoleic acid peroxidation system,

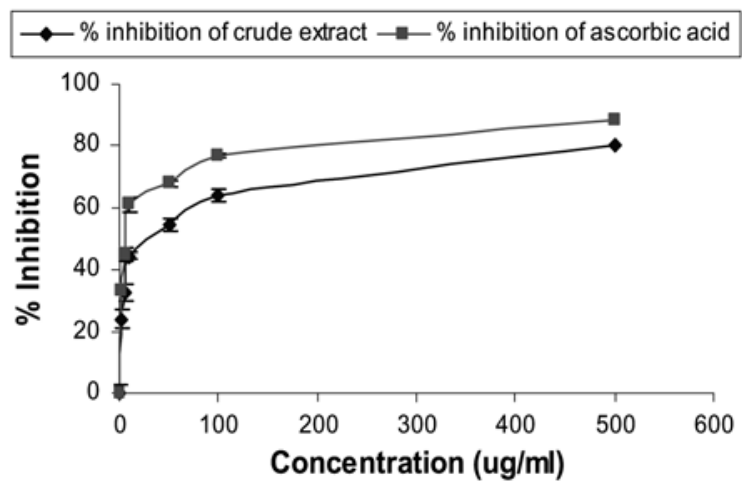

Fig. 1. DPPH scavenging assay of $R$. damascene. Probit equation for \% inhibition of ascorbic acid and crude extracts are $(y=0.1047 X+43.267)$ and $(y=0.1073 X+$ 32.561) respectively. Values are expressed as mean \pm S.D.

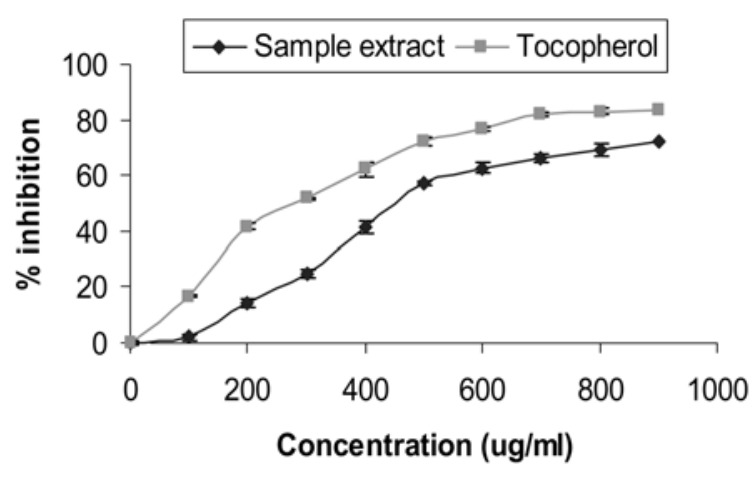

Fig. 2. Antioxidant activity of $R$. damascena extracts and $\alpha$-tocopherol in the linoleic acid peroxidation system induced by $\mathrm{FeCl}_{2}$ and $\mathrm{H}_{2} \mathrm{O}_{2}$. The activity was determined by the TBA method. Values are expressed as mean $\pm S$. D.

compared with $\alpha$-tocopherol, induced by $\mathrm{FeCl}_{2}$ and $\mathrm{H}_{2} \mathrm{O}_{2}$. The antioxidant activity of $R$. damascena extract increased with increasing concentration at the range of $200-600 \mathrm{ppm}$.

\section{Biochemical parameters}

In order to prove the possible mechanism by which $R$. damascena prevents hepatic damage caused by paracetamol, investigation on levels of AST, ALT, and ALP were carried out. AST, ALT and ALP were found to be elevated after the administration of paracetamol, which was significantly $(P<0.05)$ reversed by $R$. damascena crude extract (Table 2). These effects were comparable to control group. The control group has the value of AST, ALT, and ALP were $27.87 \pm 1.98,28.52 \pm 1.68$ and $18.21 \pm 1.04$ while the paracetamol induced increment of the marker enzyme was $62.63 \pm 1.35,67.73 \pm 2.44$ and $22.12 \pm 1.34$. The elevated enzyme level were reversed due to the pre-treatment of the $R$. damascena crude extract at the dose level of 1.5 and $3 \mathrm{~g} / \mathrm{kg}$ body weight and higher dose more significantly reduced the marker enzyme level (Table 2). The value for AST, ALT and ALP for $1.5 \mathrm{~g} / \mathrm{kg}$ body weight were $55.91 \pm 3.43,63.40 \pm 3.38,22.00 \pm 1.41$ and for $3 \mathrm{~g} / \mathrm{kg}$ body weight were $48.34 \pm 2.68,57.38 \pm 2.98$ and $20.48 \pm 0.42$. 
Table 2. Effect of methanol extracts ( 1.5 and $3 \mathrm{~g} / \mathrm{kg}$ body weight) on liver tissue damaged by paracetamol

\begin{tabular}{|c|c|c|}
\hline Animal group & Observation & Inference \\
\hline $\begin{array}{l}\text { Control (Untreated group) } \\
\text { (Group I) }\end{array}$ & $\begin{array}{c}\text { No significant change (Hepatocytes were } \\
\text { arranged from central vein in } \\
\text { a regular manner) }\end{array}$ & \\
\hline $\begin{array}{l}\text { Paracetamol treated group } \\
\text { (Group II) }\end{array}$ & $\begin{array}{c}\text { Moderated fatty changes }(++) \\
\text { Hepatocyte necrosis }(++)\end{array}$ & $\begin{array}{c}\text { Paracetamol caused injury in the } \\
\text { liver cells }\end{array}$ \\
\hline $\begin{array}{l}\text { Paracetamol + ethanol extract } \\
\text { (1.5 g/ kg body weight) }\end{array}$ & $\begin{array}{l}\text { Moderate fatty changes }(++) \\
\text { Hepatocyte necrosis not observed. }\end{array}$ & $\begin{array}{l}\text { Weakly significant activity of } \\
\text { paracetamol }\end{array}$ \\
\hline $\begin{array}{l}\text { Paracetamol + ethanol extract } \\
\text { ( } 3 \mathrm{~g} / \mathrm{kg} \text { body weight) }\end{array}$ & $\begin{array}{l}\text { Moderate fatty changes }(++) \\
\text { Hepatocyte necrosis not observed }\end{array}$ & $\begin{array}{c}\text { Weakly significant activity of } \\
\text { paracetamol }\end{array}$ \\
\hline
\end{tabular}

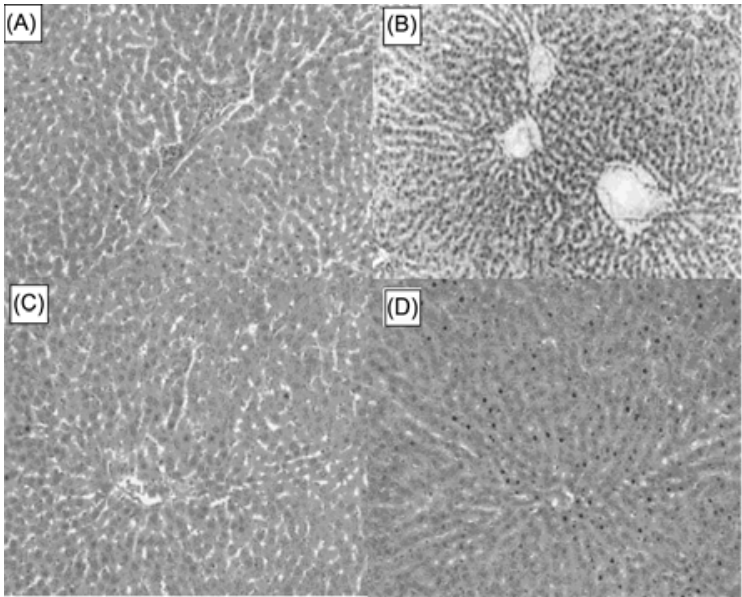

Fig. 3. Liver tissue in control group rat (A) which shows normal architecture but paracetamol treated group (B) shows fatty degeneration and necrosis. Paracetamol + ethanol extract $(1.5 \mathrm{~g} / \mathrm{kg}$ body weight $(\mathrm{C}))$ and paracetamol + ethanol extract $(3 \mathrm{~g} / \mathrm{kg}$ body weight (D)) treated group shows amelioration of the fatty degeneration and normal architecture. (Magnification X 40).

\section{Histopathologic examination}

Liver sections of control animals showed normal hepatic cells with well preserved cytoplasm, prominent nucleus and nucleolus and central vein (Table 2, Fig. 3). In paracetamol treated animals the sections showed hydropic changes in centrilobular hepatocytes with single cell necrosis surrounded by neutrophils. Congestion of central vein and sinusoids were seen with acute and chronic inflammatory cells infiltrating sinusoids mainly in the central zone. The midzonal and periportal hepatocytes showed mild to moderate degree of fatty change (Fig. 3B). Pretreatment of the animals with crude extract (1.5 and $3 \mathrm{~g} / \mathrm{kg}$ body weight) showed mild central venous congestion and mild fatty vacuolation (Fig. $3 \mathrm{C}$ and D).

\section{DISCUSSION}

Over the past 25 years, epidemiological studies have shown a diminished risk of chronic diseases in populations consuming diets high in fruits and vegetables (Pryo et al., 2000). It has been suggested that antioxidants found in large quantities in fruits and vegetables may be responsible for this protective effect (Halliwell, 1994). Generally, food antioxidants act as reducing agents, reversing oxidation by donating electrons and hydrogen ions (Groff and Gropper, 2000). Much attention has been focused on natural antioxidants and some antioxidants isolated from natural sources with high activity have been reported (Kutsuzaki et al. 1993; Okamura et al., 1993; Parasakthy et al., 1996). The antioxidant activity of $R$. damascena extract increased with increasing concentration at the range of 200-600 ppm. Iron salts are thought to react with $\mathrm{H}_{2} \mathrm{O}_{2}$, called the Fenton reaction, to make hydroxyl radicals, which are the most active free radical formed in biological systems (Hochstein and Atallah, 1988) and known to be able to abstract hydrogen atoms from membrane lipids and bring about peroxidic reactions of lipids (Fong et al., 1973; Kidata et al., 1979). From the above results, $R$. damascena extract significantly inhibits the lipid 
peroxidation derived from the Fenton reaction, indicating that the extract displayed antioxidant activity in the TBA method.

ALT and AST are two liver enzymes that are associated to the hepatocellular damage. Although both AST and ALT are common liver enzymes because of their higher concentrations in hepatocytes, only ALT is remarkably specific for liver function since AST is mostly present in the myocardium, skeletal muscle, brain and kidneys (McIntyre et al., 1987; Witthawaskul et al., 2003). In general with liver disease, serum levels of AST and ALT rise and fall at the same time (Sacher et al., 1991). A mild elevation of AST level has been shown to be associated with liver injury or myocardial infarctions (Stroev, 1989). The higher the activity of AST, the larger the infarctions size (Roberts et al., 1975; Haweroft, 1987). A typical myocardial infarction gives an AST/ALT ratio greater than 1 while an AST/ALT ratio less than 1 is as a result the release of ALT from the affected liver (Haweroft, 1987). AST/ALT ratio of more than 2 indicates alcoholic hepatitis or cirrchosis (McIntyre et al., 1987). However, crude extracts of Rosa damascena shows dose responsive effect and sufficiently decrease the serum level of ALT, AST, and ALP compared to the animal group receiving paracetamol only.

The histopatological study of the liver of different groups of rats showed a normal architecture. Rats treated orally with the extract of $R$. damascena for 7 days, Figure IV showed little abnormalities such as steatosis, clarification and balloning of hepatocytes. These signs not found in the control groups and little change is mostly seen in the rats which received 1.5 and $3 \mathrm{~g} / \mathrm{kg}$ body weight. The presence of steatosis also in the control groups suggested that this may be caused by diet of the animals. However no necrosis, infiltration, oedema and conjunction, which are the signs of hepatotoxicity, were found. The effect of $R$. damascena seems to have a protective effect on hepatocytes and improves liver architecture due to the presence of antioxidants. In conclusion, this study indicates that the alcoholic extract of $R$. damascena flowering top when taken for long periods of time may prevent paracetamol induced liver damage and may also prevent liver diseases.

\section{ACKNOWLEDGEMENTS}

Research work has been performed in Pharmacology Graduate Laboratory, Department of Pharmacology, Bangladesh Agricultural University, Mymensingh2202.

\section{REFERENCES}

Achuthan CR, Babu BH, Padikkala J. (2003) Antioxidant and hepatoprotective effects of Rosa damascena. Pharm. biol. 41, 357-361.

Alam MA, Haque ME, Shilpi JA, Daula KA. (2006a) Antinociceptive effect of the crude ethanolic extract of crataeva nurvala. Buch. on mice. Bangladesh J. Vet. Med. 4, 65-68.

Alam MA, Sarder M, Awal MA, Sikder MMH, Daulla KA. (2006b) Antibacterial activity of the crude ethanolic extract of Xylocarpus granatum stem barks. Bangladesh J. Vet. Med. 4, 69-72.

Nyeem MAB, Alam MA, Awal MA, Mostofa M, Uddin SJ, Islam N, Rouf R. (2006) CNS Depressant Effect of the Crude Extract of the Flowering Top of Rosa damascena (Rosaceae). Iran. J. Pharmacol. Therap. 5, 171-174.

Basim E, Basim H. (2003) Antibacterial activity of Rosa damascena essential oil. Fitoterapia 74, 394-396.

Fong, KL, McCay PB, Poyer JL. (1973) Evidence that peroxidation of lysomal membrane is initiated by hydroxyl radicals produced during flavin enzyme activity. J. Biol. Chem. 248, 7792-7797.

Groff J, Gropper S. (2000) Advanced Nutrition and human Metabolism, 3rd Ed. Belmont: Wadsworth.

Gupta M, Mazumdar UK, Sivahkumar T, Vamis MLM, Karki S, Sambathkumar R, Manikandan L. (2003) Antioxidant and anti-inflammatory activities of Acalypha fruticosa. Nig. J. Nat. Prod. Med. 7, 25-29.

Halliwell B. (1994) Antioxidants Sense or Speculation. Nutr. Today 29, 15-19.

Haweroft DM. (1987) Diagnostic Enzymolgy Analytical Chemistry by open Learning published by permission 
of the controller of her majesty's stationary office. pp. 186-221.

Hochstein P, Atallah AS. (1988) The nature of oxidants and antioxidant systems in the inhibition of mutation and cancer. Mutat. Res. 202, 363-375.

Joshi SG. (2004) Medicinal Plants. Oxford \& IBH Publishing Co. Pvt. Ltd. New Delhi.

Katsuzaki H, Kawakishi S, Osawa T. (1993) Structure of novel antioxidative lignan triglucoside isolated from sesame seed. Heterocycles 36, 933-936.

Kitada M, Igarashi K, Hirose S, Kitagawa H. (1979) Inhibition by polyamines of lipid peroxide formation in rat liver microsomes. Biochem. Biophys. Res. Commun. 87, 388-394.

Mahmood N, Piacente S, Pizza C, Burke A, Khan AL, Hay AJ. (1996) The anti-HIV activity and mechanisms of action of pure compounds isolated from Rosa damascena. Biochem. Biophys. Res. Commun. 229, 73-79.

McIntyre N, Rosaki S. (1987) Investigations biochimiques des affections hépatiques. pp. 294-309.

Okamura H, Mimura A, Yakou Y, Niwano M, Takahara Y. (1993) Antioxidant activity of tannins and flavonoids in Eucalyptus rostrata. Phytochemistry 33, 557-561.

Parasakthy K, Shanthi S, Deepalokshmi P, Niranjali SD. (1996) The antioxidant effect of eugenol and carbon tetrachloride induced erythrocyte damage in rats. J. Nutr. Biochem. 7, 23-28.

Pryor W, Stahl W, Rock C. (2000) Beta Carotene: From Biochemistry to Clinical Trials. Nutr. Rev. 58, 39-53.
Roberts R, Ahaymada G, Sobel B. (1975) Estimation of Infarct Size. Upjohn Co.

Sacher RA, Mcpherson RA. (1991) Widmann's clinical Interpretation of Laboratory Test. Pennsylvania. USA. pp .416-443

Shahriari S, Yasa N, Mohammadirad A, Khorasani R and Abdollahi M. (2006) In vivo Antioxidant Potentials of Rosa Damascena Petal Extract from Guilan, Iran, Comparable to á-tocopherol. Int. J. Pharmacol. 2, 137-IJP-2K6.

Stroev EA. (1989) Biochemistry, 1st ed. Mir. Moscow. pp. $425-432$.

Tamura H, Shibamoto T. (1991) Antioxidative activity measurement in lipid peroxidation systems with malonaldehyde and 4-hydroxynonenal. J. Am. Oil Chem. Soc. 68, 941- 943.

WHO. (1992) Research guidelines for evaluating the safety and efficacy of herbal medicines. Regional office for the western pacific working group on the safety and efficacy on herbal medicine. Manila, Philippines. pp 5-9.

Witthawasku P, Ampai Panthong, Kanjanapothi D, Taesothikul T, Lertprasertsuke. (2003) Acute and subacute toxicities of saponin mixture isolated from Schefflera leucantha Viguier. J. Ethnopharmacol. 89, 115-121.

Vinokur Y, Rodov V, Reznick N, Goldman G, Horev B, Umiel N, Friedman H. (2006) Rose Petal Tea as an Antioxidant-rich Beverage: Cultivar Effects. J. Food Sci. 71, S42-S47. 